\title{
NEW RECORDS OF Boletales (BASIDIOMYCOTA) IN A TROPICAL OAK FOREST FROM MEXICAN SOUTHEAST
}

\section{NueVos Registros de Boletales (BAsidiomycota) de Un ENCINAR tropical deL SURESTE MEXICANO}

\author{
Ernesto González-Chicas ${ }^{1}$, Silvia Cappello ${ }^{1 *}$, Joaquín Cifuentes ${ }^{2}$, and Magdiel TorRes-De la Cruz ${ }^{1}$
}

${ }^{1}$ Universidad Juárez Autónoma de Tabasco, Herbario UJAT, Tabasco, Mexico.

2 Universidad Nacional Autónoma de México, Herbario FCME (Hongos), CDMX, Mexico.

\begin{abstract}
Background: Derived from the study of mycobiota associated with Quercus oleoides, tropical holm oak forests in Tabasco have been explored, finding a great diversity in numerous fungal groups, such as boletoid macromycetes.

Question: What is the diversity of Boletales mycobiota associated with tropical holm oaks of Tabasco?

Species Study: Boletales, Quercus oleoides

Study sites and date: municipality of Balancán in the state of Tabasco, Mexico. 2012 - 2016.

Methods: Boletoid fungi associated with $Q$. oleoides were collected according to conventional mycological techniques. A dichotomous key of the species found was made and data on their geographical distribution are included.

Results: Nine species assigned to five genera and two families were identified.

Conclusions: Boletellus ananas, Boletus auripes, Boletus vermiculosus, Butyriboletus floridanus, Phylloporus centroamericanus, Porphyrellus indecisus, Tylopilus alboater, Gyroporus ballouii and Gyroporus castaneus are new records for the state of Tabasco, Mexico. The distribution of these species is wider than what has been reported in the literature. This work constitutes the first study of macromycetes associated with tropical holm oaks in southeastern México.
\end{abstract}

Key words: Balanan, Boletoids, Ectomycorrhiza, Macromycetes of Tabasco.

\section{Resumen}

Antecedentes: Derivado del estudio de la micobiota asociada a Quercus oleoides se han explorado los encinares tropicales en Tabasco, encontrando una gran diversidad en numerosos grupos fúngicos, como los macromicetos boletoides.

Pregunta: ¿Cuál es la diversidad de la micobiota de Boletales asociada a encinares tropicales de Tabasco?

Especie de estudio: Boletales, Quercus oleoides

Sitio y años de estudio: Municipio de Balancán en el estado de Tabasco, México 2012 - 2016.

Métodos: Se realizaron recolectas de hongos boletoides asociados a $Q$. oleoides según las técnicas convencionales de micología para su identificación taxonómica. Se realizó una clave dicotómica de las especies encontradas y se incluyen datos sobre su distribución geográfica.

Resultados: Se identificaron nueve especies adscritas a cinco géneros y dos familias.

Conclusión: Boletellus ananas, Boletus auripes, Boletus vermiculosus, Butyriboletus floridanus, Phylloporus centroamericanus, Porphyrellus indecisus, Tylopilus alboater, Gyroporus ballouii y Gyroporus castaneus son nuevos registros para el estado de Tabasco, México. La distribución de estas especies es más amplia de lo que se había reportado en la literatura. Este trabajo constituye el primer estudio de macromicetos asociados a encinares tropicales del sureste de México.

Palabras clave: Balancán, Boletoides, Ectomicorrizas, Macromicetos de Tabasco. 
The order Boletales is one of the most diverse groups of macromycetes, including 2,173 species that belong to 19 families (Catalogue of Life 2018). These fungi present a wide variety of forms in their fruiting bodies and can be resupinate or crust-like with smooth, merulioid, or hydnoid hymenophores; gasteroid (puffball-like); polypore-like, as in the unique case of Bondarcevomyces taxi (Bondartsev) Parmasto; and a typical mushroom form (stipe and pileus), a fleshy body and a hymenophore composed of gills (lamellae) or tubes. The configuration of tubular hymenophores is the most common of the Boletaceae family, which is referred as boletoid form (Binder \& Hibbett 2006).

The majority of the boletoid fungi form ectomycorrhizal associations with numerous photobionts in temperate forests as well as tropical regions. These fungi are important for all forest ecosystems worldwide because they are the main recyclers of organic matter, nutrient uptake, and even nutrient transport within the forest system (Halling et al. 2007). This type of fungi is greatly valued as edible food for several human cultures (Carrasco-Hernández et al. 2010). In general, boletoid fungi are associated with conifers in temperated forest. A small number of this species have been reported in tropical regions, association to Salicaceae Myrtaceae and mainly Fabaceae (Pérez-Moreno \& Read 2004), is probably due to the lack of more comprehensive studies in tropical forest.

Mexico is a world center of oaks richness and endemisms (Manos et al. 1999, Valencia-A 2004, Varela-Fregoso et al. 2017, Cavender-Bares 2018), it has been observed that there is a correspondence also of a high boletoid diversity, shown by the recent report of mycorrhizal fungi (García-Jiménez \& Garza-Ocañas 2001, Chávez-Vergara et al. 2016, VarelaFregoso et al. 2017), even though oak forests represent only
$5.5 \%$ of the vegetation cover of Mexico (López-Upton et al. 2011).

The natural distribution of the tropical oak Quercus oleoides Schltdl. et Cham. (Figure $1 \mathrm{~A}-\mathrm{B}$ ) extends from $23{ }^{\circ} \mathrm{N}$ from the state of Tamaulipas, Mexico to $10^{\circ} \mathrm{N}$ to the Guanacaste province of Costa Rica, including parts of Honduras, Belize, and Nicaragua (Fournier 2003; Romero-Rangel et al. 2015, Pérez-Mojica \& Valencia-A 2017). In Tabasco, Mexico, fragments of $Q$. oleoides are found, mainly in the municipality of Balancán (Cámara et al. 2011, Cámara \& Cappello 2013). These fragments are relicts resulting from the displacement that occurred during the most recently recorded glacial periods, these oak trees were able to adapt to the warm-humid climate conditions. Furthermore, these tropical oak forests are considered an important refuge of the flora and fauna during the Pleistocene (Prance 1982, Pennington \& Sarukhán 2005). Therefore, it is imperative to continue studying the mycobiota associated with oak. Additionally, this would contribute to the understanding of the biota associated with these forests which in turn would help to develop preventive strategies, recovery and loss of this habitat.

\section{Materials and methods}

Study site. It was carried out in the municipality of Balancán in the state of Tabasco, Mexico. In this location $Q$. oleoides is found fragmented and associated with different types of vegetation, mainly grasssland. This entire area corresponds to the ecogeographical unit Terraces of Balancán (Figure 2) and the Terrace subprovince, which contains structural plains dating to the Miocene period, with an elevation ranging from 0 to $50 \mathrm{~m}$ (Ortiz-Pérez et al. 2005). The climate is

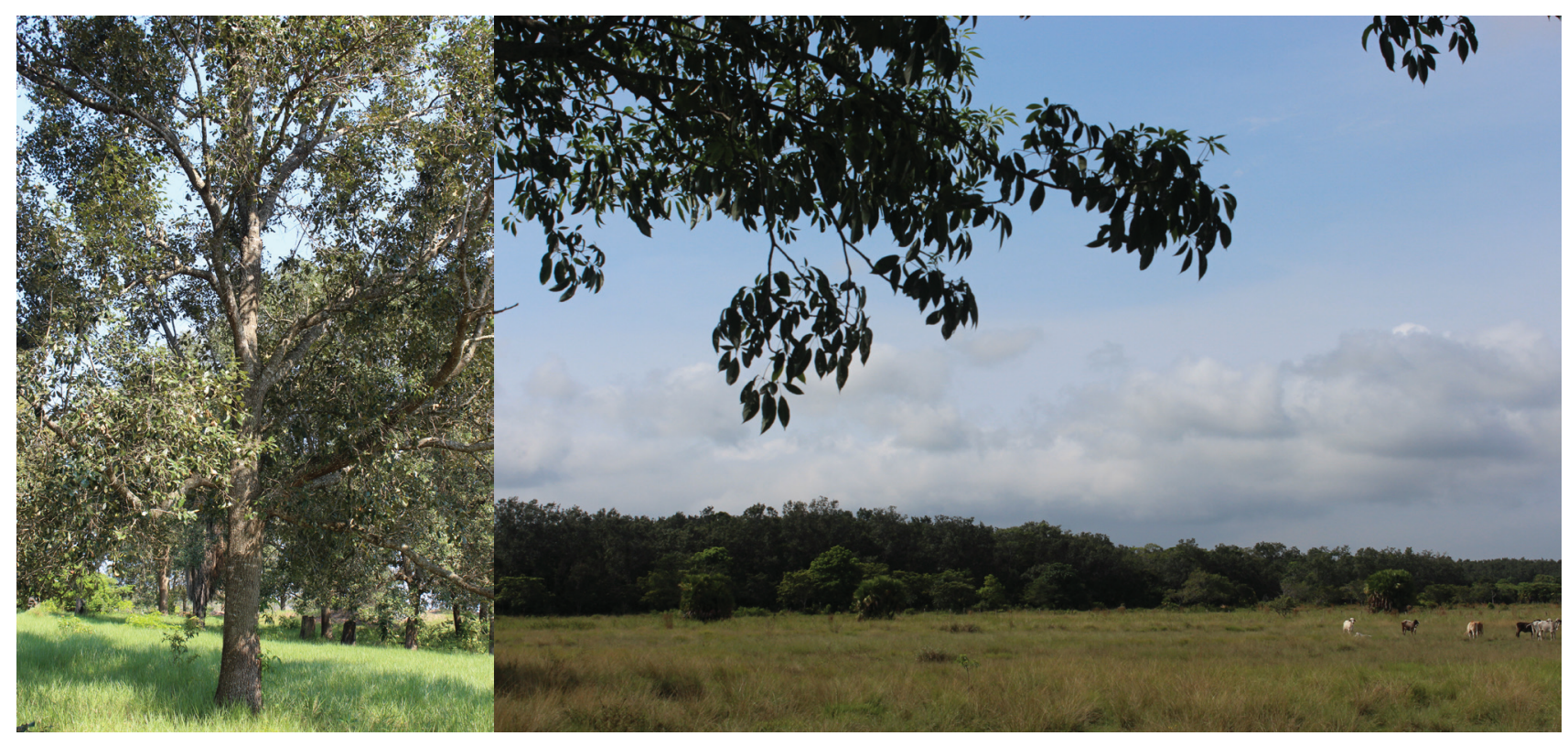

Figure 1. A) Quercus oleoides in youth stage. B) Oak forest fragmented by livestock activities. 

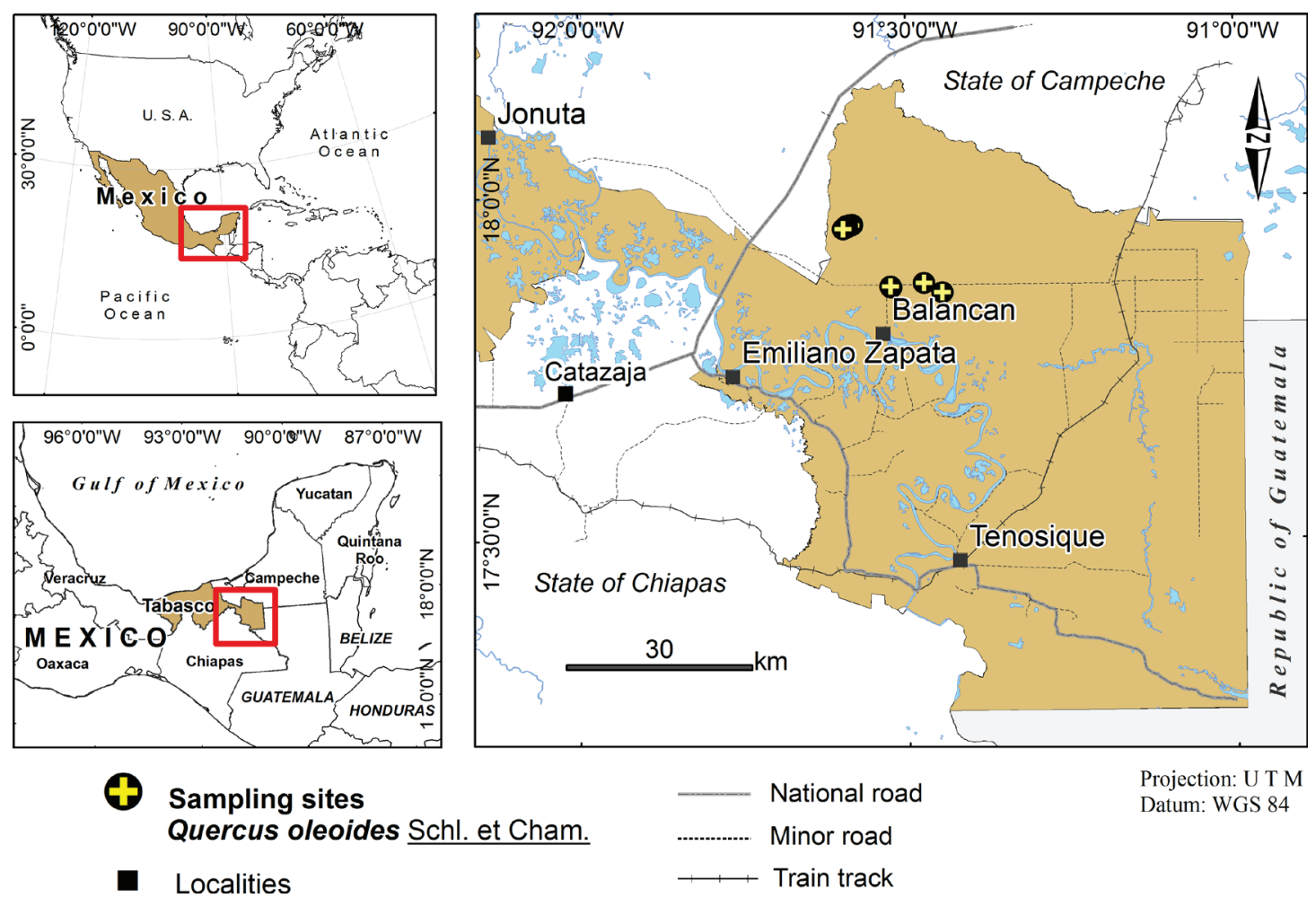

Figure 2. Sampling sites of oak forest in Balancán, Tabasco.

warm-subhumid (Am), and most of the rainfall occurs during the wet summer (García 2004), with 1,200-1,400 mm from May to October and 400-500 mm from November to April (INEGI 2009).

The localities mostly coincided with the ejido "El Pípila," which contains a secondary forest where $Q$. oleoides dominates, as well as with several ranches along the Balancán-El Triunfo road, associated with grassland or pasture. In both localities, the oak vegetation is highly fragmented due to livestock grazing, as the land is largely private owned. The specific collection sites are shown in Appendix 1.

Data collection. The two collection sites of the boletoids associated with the oak vegetation are within an area of 100 $\mathrm{m}^{2}$. Boletoid basidiomes were collected following conventional mycological techniques (Cifuentes et al. 1986, Cappello 2006). Küppers (2002) guide was used to describe the color of the basidiomes. The specimens were herborized and deposited in the UJAT Herbarium, located in the Academic Division of Biological Sciences at the Universidad Juárez Autónoma of Tabasco (UJAT), and duplicates were deposited in the Herbarium of the Faculty of Sciences (FCME), Universidad Nacional Autónoma de México (UNAM). The sites were visited in the rainy seasons during the period 2012 to 2016. Specimens previously collected, present in the Herbarium of UJAT, were also reviewed for this work. For each sample, photographs were taken in the field and during laboratory study. Description of the microscopic structures used
Largent et al. (1977) terminology. Specimens were observed with a Zeiss Axiostar Plus microscope using phase-contrast microscopy. Spores, basidia, and cistidia were measured using AxioVision 40 V4.7.1.0. software. For the taxonomic identification specialized bibliography was used (Smith \& Thiers 1971, Montoya \& Bandala 1991, García-Jiménez \& Garza-Ocañas 2001, Halling et al. 2007, Halling et al. 2008, Neves \& Halling 2010). The Index Fungorum (2018) was used to identify the current names use, classification, nomenclature and synonymy for the studied fungi in this work.

\section{Results}

Twenty four specimens were identified at the species level, belonging to two families, seven genera, and nine species. The best-represented family was Boletaceae, with five genera and seven species, followed by the family Gyroporaceae, which was represented by Gyroporus ballouii and G. castaneus (Table 1).

Key to boletoid species from the oak forest of the Mexican southeast.

1a. Hymenophore tubular . . . . . . . . . . . . . 2

1b. Hymenophore lamellate . . . . . . . . . . . . ................. Phylloporus centroamericanus 2a. Context and hymenophore change when cutting ..... 3 2b. Context and hymenophore not bruising blue when cut-

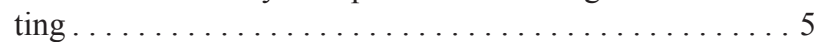


Table 1. Taxonomic list of the boletoid fungi found in the sampling sites.

\begin{tabular}{ll}
\hline Family & Species \\
\hline Boletaceae Chevall., & Boletellus ananas (M. A. Curtis) Murrill \\
& Boletus auripes Peck \\
& Boletus vermiculosus Peck \\
& Butyriboletus floridanus (Singer) G. Wu, Kuan Zhao \& Zhu L. Yang \\
& Phylloporus centroamericanus Singer y L.D. Gómez \\
& Porphyrellus indecisus (Peck) E.-J. Gilbert \\
& Tylopilus alboater (Schwein.) Murrill. \\
& Gyroporus ballouii (Peck) E. Horak. \\
Gyroporaceae Manfr. Binder \& Bresinsky & Gyroporus castaneus (Bull.) Quél. \\
\hline
\end{tabular}

3a. Pores reddish $\ldots \ldots \ldots \ldots \ldots \ldots \ldots \ldots \ldots \ldots$

3b. Pores yellowish . . . . . . . . . Boletellus ananas

4a. Pileus vinaceous-pink, strongly reticulated reddish stipe ...................... Butyriboletus floridanus 4b. Pileus brown, non reticulated non reddish stipe. ...... ......................... Boletus vermiculosus 5a. Hymenophore with greenish yellow tints . . . . . . . .

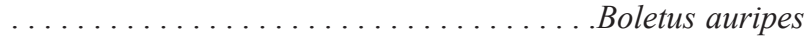
5b. Hymenophore without greenish yellow tints . . . . . 6 6a. Stipe hollow. . . . . . . . . . . Gyroporus castaneus 6b. Stipe always solid . . . . . . . . . . . . . 7 7a Pileus bright orange ............ Gyroporus ballouii 7b Pileus brown to dark tints . . . . . . . . . . 8 8a. Pileus ochraceus to pale brown. .Porphyrellus indecisus 8b. Pileus black to dark grayish brown . Tylopilus alboater

Boletellus ananas (M. A. Curtis) Murrill., Mycologia 1 (1): 10 (1909) (Figure 3-A) EBoletus ananas M. A. Curtis, Amer. J. Art Scienc. 6: 351 (1848) =Suillus ananas (M. A. Curtis) Kuntze, Revis. Gen. Pl. (Leipzig) 3(2): 535 (1898). Examined material: México. Tabasco, Balancán, Ranch Don Filemón, road Ej. El Pípila-Ej. San Elpidio, km 0.5, terrestrial, alt $30 \mathrm{~m}$, tropical oak, 11/01/2015. C. E. González-Chicas 3895 (UJAT). Distribution: The distribution extends from the southeastern United States to Mexico, Costa Rica, Guyana and Colombia. Addcional records have been found in Asia, New Zealand and New Caledonia, associated to different hosts (Singer et al. 1992, Mata 1999, Mayor et al. 2008, García-Jiménez 2013, Ayala-Vásquez et al. 2018). Taxonomic comments: This unique boletoid is easily recognizable by its pileus with notable scales, white to soft reddish in color $\left(\mathrm{Y}_{60} \mathrm{M}_{60} \mathrm{C}_{00}\right)$, with yellowish color $\left(\mathrm{Y}_{60} \mathrm{M}_{00} \mathrm{C}_{00}\right)$ himenium, which will turn blue $\left(\mathrm{N}_{50} \mathrm{C}_{80} \mathrm{Y}_{30}\right)$ when touched and darken as they age. These fungi were found at the base of oak trees. Our specimen coincided with those reported by Mata (1999) and Halling \& Mueller (2005), basidiospores show longitudinal and transverse striations. This fungus is also found under the $Q$. oleoides in Costa Rica. In Belize, Ortiz-Santana et al. (2007) reported this species with the name Boletellus coccineus (Sacc.) Singer. We decided to consider B. coccineus as synonymous to $B$. ananas as established by Halling et al. (2015).
Boletus auripes Peck, Rep. (Annual) New York State Mus. Nat. Hist. 50:107 (1898) (Figure 3-B). Examined material: Mexico. Tabasco, Balancán, Ranch Don Filemón, road Balancán -El Triunfo, km 8.3, terrestrial, alt $30 \mathrm{~m}$, tropical oak, 20/06/2015. Cappello G.S. 3894 (UJAT); Don Filemón, road Ej. El Pípila-Ej. San Elpidio km 0.5, terrestrial, alt $30 \mathrm{~m}$, tropical oak, 20/06/2015. Cappello S. G. 3893 (UJAT). Distribution: Northern America, including Canada, Florida, and New York; northern and central Mexico, and Belize; also recorded in China, Japan and Taiwan in Asia, and recently recorded in east of Russia in association with different hosts (Chen et al. 1997, Bessette et al. 2000, García-Jiménez \& Garza-Ocañas 2001, Ortiz-Santana et al. 2007, Bulakh 2008). Taxonomic comments: This species is easily recognized by the yellowish brown-brown $\left(\mathrm{N}_{20} \mathrm{Y}_{80} \mathrm{M}_{40}\right)$ color of its pileus, which becomes paler with age and the lack of blue staining anywhere when bruised. This bolete have flesh yellowish-pale $\left(\mathrm{N}_{00} \mathrm{Y}_{10} \mathrm{M}_{00}\right)$, stipe yellow or weak yellow $\left(\mathrm{N}_{00} \mathrm{Y}_{10} \mathrm{M}_{00}\right)$, reticulated near the apex. The concept of $B$. auripes sensu (Singer 1947) differs from that of Ortiz-Santana et al. (2007) for its larger basidiospores (11-14.9 × 3.9-5.2 $\mu \mathrm{m}$ vs. 9.6-12.8 × 3.2-4.8). We found both sizes of the spores in the study area; therefore, we consider that the $B$. auripes concept is broader than what is believed.

Boletus vermiculosus Peck, Rep. (Annual) New York State Mus. Nat. Hist. 23:130 (1872) (Figure 3-D). Examined material: Mexico. Tabasco, Balancán, Ranch Don Filemón, road Balancán -El Triunfo km 8.3 terrestrial, alt $30 \mathrm{~m}$, tropical oak, 16/06/2013. González-Chicas C. E. 3899 (UJAT); Ranch Don Filemón, oak Ej. El Pípila-Ej. San Elpidio km 0.5 , terrestrial, alt $30 \mathrm{~m}$, tropical oak, 21/03/2015. GonzálezChicas C. E. 3900 (UJAT); Rancho Don Filemón, Ej. El Pípila-Ej. San Elpidio km 0.5, alt 30 m, tropical oak, 20/06/2015. Cappello S. G. 3893 (UJAT). Distribution: Wide distribution from eastern Canada to Georgia and western Michigan in the United States, Guerrero in Mexico, Belize, and southern Costa Rica, always in symbiosis with trees of the genus Quercus (Bessette et al. 2000, Cifuentes et al. 1993, Halling \& Mueller 2005, Ortiz-Santana et al. 2007). Taxonomic comments: This species is characterized by the reddish-brown 


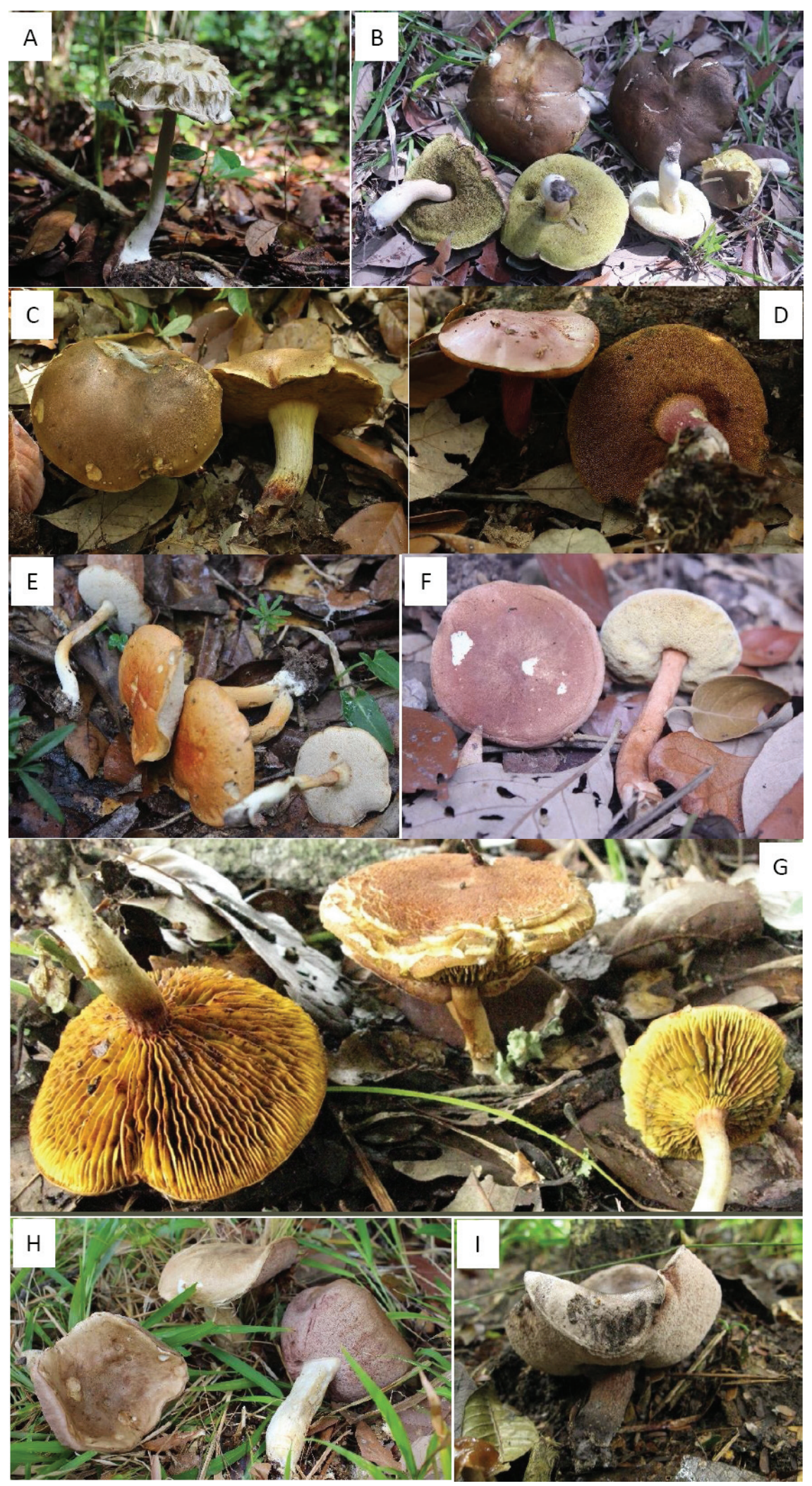

Figure 3. Basidiomes of the species found. A) Boletellus ananas, B) Boletus auripes, C) Butyriboletus floridanus, D) Boletus vermiculosus, E) Gyroporus ballouii, F) Gyroporus castaneus, G) Phylloporus centroamericanus, H) Porphyrellus indecisus and I) Tylopilus alboater. 
$\left(\mathrm{N}_{60} \mathrm{Y}_{30} \mathrm{M}_{80}\right)$ color of the pores, pale brown $\left(\mathrm{N}_{20} \mathrm{Y}_{60} \mathrm{M}_{30}\right)$ color and a velvety surface of the pileus, pruinose stipe, and blue $\left(\mathrm{N}_{80} \mathrm{C}_{60} \mathrm{Y}_{20}\right)$ color of the flesh and tubes upon cutting are diagnosis characters for this species. This taxon can be confused with Boletus vermiculosoides A.H. Sm. and Thiers, which mainly differs for having slightly larger basidiospores (9-12 $\mu \mathrm{m} v \mathrm{~s} .10-15 \mu \mathrm{m})$, and with $B$. subgraveolens A.H. Sm. and Thiers, which is distinguished by its unpleasant odor (of urine) after being herborized in contrast with the common fungal odor of B. vermiculosus (Smith \& Thiers 1971). Our specimen better coincides with the concept of $B$. vermiculosus of Ortiz-Santana et al. (2007). In addition to the previously mentioned characteristics, an intense red coloration was observed at the base of the stipe. This peculiarity had not been mentioned for the North American concept (Smith \& Thiers 1971, Bessette et al. 2000). Molecular analyses are needed to clarify the limits between the above-mentioned taxa.

Butyriboletus floridanus (Singer) G. Wu, Kuan Zhao and Zhu L. Yang. Fungal Diversity Res. Ser. 81:72 (2016) (Fig. 3-C). 三Boletus frostii subsp. floridanus Singer, Mycologia 37: 799 $(1945)=$ Boletus floridanus (Singer) Murril, Lloydia 11: 23 (1948) =Suillellus floridanus (Singer) Murrill, Lloydia 11: 29 (1948) =Exsudoporus floridanus (Singer) Vizzini, Simonini \& Gelardi, Index Fungorum 183: 1 (2014). Examined material: Mexico. Tabasco, Balancán, Ranch Don Filemón, road Ej. El Pípila-Ej. San Elpidio, km 0.5, terrestrial, $30 \mathrm{~m}$ altitud, tropical oak, 21/03/2015. González-Chicas C. E. 3902 (UJAT). Distribution: The United States, including Tennessee, South Carolina, and Florida; northeastern Mexico in Tamaulipas; and recently Belize always in symbiosis with trees of the genus Quercus (Bessette et al. 2000, GarcíaJiménez \& Garza-Ocañas 2001, Ortiz-Santana et al. 2007). Taxonomic comments: Butyriboletus floridanus, is easily recognizable by the violet to red $\left(\mathrm{Y}_{80} \mathrm{M}_{90} \mathrm{C}_{40}\right)$ color of the pileus, reddish $\left(\mathrm{Y}_{80} \mathrm{M}_{90} \mathrm{C}_{00}\right)$ hymenophore and small pores (2$3 / \mathrm{mm})$. Our specimen coincides with the description of OrtizSantana et al. (2007) under the name of Boletus floridanus.

Gyroporus ballouii (Peck) E. Horak, Malayan Forest Rec. 51: 42 (2011) (Figure 3-I) $\equiv$ Boletus balloui Peck, Bull. New York State Mus. Sci. Serv. 157: 22. (1912) [1911] = Boletus balloui Peck, Bulletin of New York State Museum of Natural History 157: 22. (1912) [1911] var. balloui = Gyrodon balloui (Peck) Snell, Mycologia 33: 422. (1941) = Rubinoboletus balloui (Peck) Heinem. \& Rammeloo, Bull. Jard. Bot. Natl. Belg. 53 (1/2): 295 (1983) = Rubinoboletus balloui (Peck) Heinem. \& Rammeloo, Bull. Jard. Bot. Natl. Belg. 53 (1/2): 295 (1983) f. balloui = Rubinoboletus balloui f. persicinus Watling \& T.H. Li, Australian Boletes: 50 (1999) = Rubinoboletus balloui (Peck) Heinem. \& Rammeloo, Bull. Jard. Bot. Natl. Belg. 53 (1/2): 295 (1983) var. balloui $=$ Rubinoboletus balloui var. luteoporus Heinem. \& Rammeloo, Bull. Jard. Bot. Natl. Belg. 53 (1/2): 296 (1983) $=$ Rubinoboletus balloui var. viscidus T.H. Li \& Watling [as "ballouii”], Edinburgh J. Bot. 56(1): 145 (1999) = Tylopilus balloui (Peck) Singer [as "ballouii”], Amer. Midl. Naturalist. 37: 104 (1947). Examined material: Mexico.
Tabasco, Balancán, road Balancán -El Triunfo km 8.3, terrestrial, alt $30 \mathrm{~m}$, tropical oak, 22/12/2012. González-Chicas C. E. 3874 (UJAT); 09/11/2012. González-Chicas C. E. 3873 (UJAT); 02/11/2015. González-Chicas C. E. 3877 (UJAT); 03/02/2013. González-Chicas C. E. 3875 (UJAT). Distribution: Wide distribution from the eastern United States and Tamaulipas in northeastern Mexico to Belize and Costa Rica always in symbiosis with trees of the genus Quercus; also recorded in Asia, in association with different hosts (Bessette et al. 2000, Halling et al. 2007, Cifuentes 2008, Osmundson \& Halling 2010, García-Jiménez 2013).

Taxonomic comments: Our specimen corresponds with the concept of Tylopilus ballouii (Peck) Singer of Bessette et al. (2000) and Ortiz-Santana et al. (2007), although, the current name in the index Fungorum for this species is $G y$ roporus ballouii. This taxon is complex according to Halling et al. (2008).

Gyroporus castaneus (Bull.) Quél., Enchir. fung. (Paris): 161 (1886) (Figure 3-J). 三 Boletus castaneus Bull., Herb. Fr. (Paris) 7: t. 328 (1787). = Suillus castaneus (Bull.) P. Karst., Bidr. Känn. Finl. Nat. Folk 37: 1 (1882). = Suillus castaneus (Bull.) Kuntze, Revis. Gen. Pl. 3(3): 535 (1898) = Leucobolites castaneus (Bull.) Beck, Z. Pilzk. 2(7): 142 (1923) = Boletus fulvidus Fr., Observ. Mycol. (Havniae) 2: 247 (1818). = Boletus testaceus Pers., Mycol. Eur. (Erlanga) 2: 137 (1825). Examined material: Mexico. Tabasco, road Balancán -El Tri-

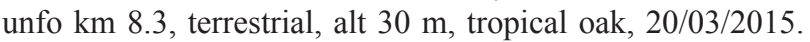
González-Chicas C. E.3879, (UJAT); 14/11/2015 GonzálezChicas C. E. 3881 (UJAT); 20/06/2015. Cappello G.S. 3880 (UJAT); 27/02/2016. Cappello S. G. 3882 (UJAT); Rancho Don Filemón, road Ej. El Pípila-Ej. San Elpidio km 0.5, terrestrial, alt $30 \mathrm{~m}$, tropical oak, 06/12/2015. Cappello $S$. G. 3883 (UJAT). Distribution: Wide distribution in Europe and North America, from eastern Canada to Florida in the United States, Mexico, Belize, and Costa Rica in association with different hosts (González-Velázquez \& Valenzuela 1996, Bessette et al. 2000, Ortiz-Santana et al. 2007). Taxonomic comments: This species is easy to recognize by the chestnutbrown $\left(\mathrm{N}_{30} \mathrm{Y}_{50} \mathrm{M}_{30}\right)$ to brown $\left(\mathrm{N}_{30} \mathrm{Y}_{70} \mathrm{M}_{40}\right)$ color of its pileus, off white $\left(\mathrm{N}_{00} \mathrm{M}_{00} \mathrm{C}_{00}\right)$ hymenophore, and hollow and fragile stipe. In spite of having a wide distribution, our specimen coincides with the concept of Ortiz-Santana et al. (2007), with smaller basidiospores than the European-North American concept $(6-8 \times 3-4 \mu \mathrm{m} v s .8-13 \times 5-6 \mu \mathrm{m})$. Davoodian et al. (2018) concluded that $G$. castaneus is a complex species with representatives in Europe and North America (including Central America) as well as eastern Eurasia.

Phylloporus centroamericanus Singer \& L.D. Gómez, Brenesia 22: 169 (1984) (Figure 3-E). Examined material: Mexico. Tabasco, Balancán, road Balancán -El Triunfo km 8.3, terrestrial, alt $30 \mathrm{~m}$, tropical oak, 02/02/2013. González-Chicas C. E. 3886 (UJAT); 17/06/2013. González-Chicas C. E. 3906 (UJAT); Rancho Don Filemón, road Ej. El Pípila-Ej. San Elpidio km 0.5, terrestrial, alt $30 \mathrm{~m}$, tropical oak, 01/11/2015. Mondragón-Sánchez A. 3888 (UJAT); 17/06/2015. Mondragón-Sánchez A.3887 (UJAT). Distribution: In southeast- 
ern Mexico and Costa Rica, always in symbiosis with trees of the genus Quercus (Montoya \& Bandala 1991, Neves \& Halling 2010). Taxonomic comments: Our specimen coincides with the concepts of Singer \& Gómez (1984) and Neves \& Halling (2010). It is distinguishable from other species of the genus by the reddish-brown $\left(\mathrm{Y}_{70} \mathrm{M}_{80} \mathrm{C}_{20}\right)$ tones of the pileus. Furthermore, the pileus surface reacted to $\mathrm{NH}_{4} \mathrm{OH}$, producing a blue $\left(\mathrm{Y}_{00} \mathrm{M}_{40} \mathrm{C}_{99}\right)$ color. Basidiospores were of 9-14 $\times 4-5$ $\mu \mathrm{m}$ and had very conspicuous cystidia $(45-100 \times 10-20 \mu \mathrm{m})$ with thick walls $(2-4 \mu \mathrm{m})$.

Porphyrellus indecisus (Peck) E.-J. Gilbert, Les Livres du Mycologue Tome I-IV, Tom. III: Les Bolets: 99 (1931). (Figure 3-H). $\equiv$ Boletus indecisus Peck, Rep. (Annual) New York State Mus. Nat. Hist. $41: 76$ (1888). = Tylopilus indecisus (Peck) Murril, Mycologia 1(1): 15 (1909) = Tylopilus indecisus (Peck) Murril, Mycologia 1(1): 15 (1909) var. indecisus $=$ Tylopilus indecisus var. subpunctipes (Peck) Wolfe, Sydowia 34: 211 (1981) = Boletus subpunctipes Peck, Bull. New York State Mus. Nat. Hist. 116: 19 (1907). = Tylopilus subpunctipes (Peck) A.H. Sm. andThiers, Boletes of Michigan (Ann Arbor): 119 (1971). Examined material: Mexico. Tabasco, Balancán, Ranch Don Filemón, road Ej. El Pípila-Ej. San Elpidio km 0.5, terrestrial, alt $30 \mathrm{~m}$, tropical oak, 09/10/2014. Cappello G.S. 3891 (UJAT); 02/12/2015. Cappello G.S. 3892 (UJAT). Distribution: From New York to western California in United States; also recorded in Guerrero in Mexico, always in symbiosis with trees of the genus Quercus (Thiers 1975, Bessette et al. 2000, Cifuentes 2008).

Taxonomic comments: When mature, the rosy $\left(\mathrm{N}_{00} \mathrm{M}_{10} \mathrm{C}_{00}\right)$ color of the pore surface turns brown $\left(\mathrm{N}_{60} \mathrm{Y}_{30} \mathrm{M}_{40}\right)$ upon contact. Flesh is soft and remains white $\left(\mathrm{N}_{00} \mathrm{M}_{00} \mathrm{C}_{00}\right)$ upon being cut. Apex of the stipe slightly reticulated and off-white $\left(\mathrm{N}_{00} \mathrm{M}_{00} \mathrm{C}_{00}\right)$ in color, placing our specimen in the "indecisus" lineage according to Smith \& Thiers (1971). The absence of globular pigment in the hyphae of the cuticle, as observed during reaction with Meltzer's reagent, defines our specimen as Tylopilus indecisus (Peck) Murrill (currently named Porphyrellus indecisus), coinciding with the specimens presented by Smith \& Thiers (1971).

Tylopilus alboater (Schwein.) Murrill., Mycologia 1 (1): 16 (1909) (Figure 3-F) $\equiv$ Boletus alboater Schwein., Schriften der Naturforschenden Gesellschaft zu Leipzig 1: 95 (1822). = Porphyrellus alboater (Schwein.) E.-J. Gilbert, Les livres du Mycologue Tome I-IV, Tom. III: Les Bolets: 99 (1931). Examined material: Mexico. Tabasco, Balancán, road Balancán -El Triunfo $\mathrm{km} \mathrm{8.3,} \mathrm{terrestrial,} \mathrm{alt} 30 \mathrm{~m}$, tropical oak, 03/02/2013. González-Chicas C. E. 3897 (UJAT); 08/11/2012. González-Chicas C. E. 3896 (UJAT); Ranch Don Filemón, road Ej. El Pípila-Ej. San Elpidio km 0.5, terrestrial, alt $30 \mathrm{~m}$, tropical oak, 01/11/2015. González-Chicas C. E. 3898 (UJAT). Distribution: Quebec in Canada, eastern United States, and eastern Mexico in Tamaulipas. Also recorded in China, Japan, Taiwan and Thailand in Asia in association with different hosts (Zhishu et al. 1993, Bessette et al. 2000, Seehanan et al. 2007, García-Jiménez 2013). Taxo- nomic comments: Corresponds with the concept of Smith \& Thiers (1971) with respect to basidiospores $(9-11 \times 3-4 \mu \mathrm{m})$ and microchemical reactions. Tylopilus griseocarneus Wolfe and Halling is very similar yet has gray flesh. In comparison, T. alboater has white flesh, similar to our specimen.

\section{Discussion}

When comparing our results with previous studies from Neotropics and North America (Smith \& Thiers 1971, Bessette et al. 2000, Lodge et al. 2002, Halling \& Mueller 2005, Ortiz-Santana et al. 2007, Henkel et al. 2012, García-Jiménez 2013), we found a great resemblance to the North American boletoid species. This is likely due to the distribution of the genus Quercus in the study area. Additionally, the observed coincidence of these species to others from Belize and Costa Rica is due to the distribution of $Q$. oleoides in both countries.

According to the literature, the geographical distribution of the species studied, three groups are distinguished. The first group is composed of two species (B. floridanus and $P$. centroamericanus) and presents a distribution restricted to the southeastern United States, the mixed forests along the eastern coast of Mexico, Belize, and Costa Rica. The second group is also formed by two species (B. vermiculosus and $P$. indecisus) and has a more northern distribution up to eastern Canada and across the United States, in both Georgia and the west in California. The distribution then extends toward Mexico with records in the state of Guerrero, and also to Belize and Costa Rica. Finally, group three is formed by five species (B. ananas, B. auripes, T. alboater, G. ballouii, and $G$. castaneus) with a wide distribution across the American continent and reported also in Europe, Asia, and Oceania. The wide distribution of group three, according to Halling et al. (2008), could be the result of the historical distribution developed during the original Pangaea continent, about 300 million years ago. Along with their phytobionts, these species could have begun to diversify as the continental masses of Laurasia and Gondwana detached from each other. Then, uncovered portions of land could have functioned as "bridges" between the continental masses, resulting in a convergence of species between these supercontinents. Several examples are found in Central America in the Western Hemisphere and the Malaysian archipelago located at the Wallace Line in the Eastern Hemisphere (Matheny \& Bougher 2006). Both areas are connected as part of what was once Laurasia (North America and Asia) with Gondwana (South America and Oceania) (Heckman et al. 2001). For this reason, these taxa likely form large species complexes. Therefor, they should be further clarified. A more comprehensive taxonomy is required that integrates molecular, chemotaxonomic, morphological and ecological characters.

\section{Acknowledgments}

The first author thanks the tenant farmers of the ejido "El Pípila", and the Engineer Ricardo Ramírez for the facilities provided, and the Macromycete Laboratory of the UJAT 
Herbarium for the support provided. All authors are grateful for the financing provided by the projects FOMIX-CONACYT "Diversidad y conservación de los hongos macro y microscópicos saprobios de algunos ambientes del parque estatal Agua Blanca, Macuspana, Tabasco" (TAB-2009C18-122083) and "Contribuciones monográficas de la biodiversidad de macromicetos mexicanos" (UNAM PAPIIT IN207311).

\section{Literature cited}

Ayala-Vásquez O, Valenzuela R, Aguirre-Acosta E, Raymundo T, García-Jiménez J. 2018. Species of Boletaceae (Boletales, Basidiomycota) with ornamented spores from temperate forests at the state of Oaxaca, México. Studies in Fungi 3: 271-292. DOI: https://doi.org/10.5943/sif/3/1/28

Bessette AE, Roody WC, Bessette AR. 2000. North American boletes, a color guide to the fleshy pored mushrooms. Syracuse University Press, New York. ISBN 0815605889 , 9780815605881

Binder M, Hibbett D. 2006. Molecular systematics biological diversification of Boletales. Mycologia 98: 971-981. DOI: https://doi.org/10.1080/15572536.2006.11832626

Bulakh EM. 2008. Species of agaricoid fungi new for Russia and Russian Far East. Mikologiya i Fitopatologiya 42: 417-25.

Cámara LC, Hernández-Trejo H, Castillo-Acosta O, GalindoAlcántara A, Morales A, Zequeira-Larios C, Rullán-Ferrer C, Guadarrama M. 2011. Estudio Regional Forestal de la UMAFOR de los ríos. Informe técnico. Tabasco (UJAT)División Académica de Ciencias Biológicas (DACBiol). Villahermosa: Comisión Nacional Forestal (CONAFOR).

Cámara LC, Cappello S. 2013. Manual del jardín botánico universitario José Narciso Rovirosa. Tabasco: Universidad Juárez Autónoma de Tabasco. ISBN: 9786076060964

Cappello S. 2006. Hongos del YUMKA'. Tabasco: Universidad Juárez Autónoma de Tabasco. ISBN: 9685748942

Carrasco-Hernández V, Pérez-Moreno J, Espinosa-Hernández V, Almaraz-Suárez J, Quintero-Lizaola R, Torres-Aquino M. 2010. Caracterización de micorrizas establecidas entre dos hongos comestibles silvestres y pinos nativos de México. Revista Mexicana de Ciencias Agrícolas 1: 557-567.

Catalogue of life-Annual Checklist $<$ http://www.catalogueoflife. org/col/browse/tree/id/8e43417ba4bde2d9eb861 cac5e4bf8b> (Accessed September 5, 2018).

Cavender-Bares J. 2018 Diversification, adaptation, and community assembly of the American oaks (Quercus), a model clade for integrating ecology and evolution. New Phytologist. DOI: https://doi.org/10.1111/nph.15450

Chávez-Vergara B, Rosales-Castillo A, Merino A, VázquezMarrufo G, Oyama K, García-Oliva F. 2016. Quercus species control nutrients dynamics by determining the composition and activity of the forest floor fungal community. Soil Biology \& Biochemistry 98: 186-195.

DOI: http://dx.doi.org/10.1016/j.soilbio.2016.04.015

Chen CM, Huang HW, Yeh KW. 1997. The Boletes of Taiwan (VII). Taiwania 42: 9-174.

DOI: https://doi.org/10.6165/tai.1997.42.174

Cifuentes J, Villegas M, Pérez-Ramírez L. 1986. Hongos. In: Lot
A, Chaing F. eds. Manual de Herbario. Ciudad de México: Consejo nacional de la flora de México A.C., 55-64. ISBN: 9686144005

Cifuentes J, Villegas M, Pérez-Ramírez L. 1993. Hongos macroscópicos. In: Luna-Vega, Llorente J. eds. Historia natural del Parque Ecológico Estatal Omiltemi, Chilpancingo Guerrero, México. Ciudad de México: Comisión Nacional para el Conocimiento y Uso de la BiodiversidadUniversidad Nacional Autónoma de México, 59-126. ISBN: 9683633633

Cifuentes J. 2008. Catálogo de autoridades taxonómicas de los hongos de México. Base de datos del sistema nacional de información sobre biodiversidad. Comisión Nacional para uso y manejo de la Biodiversidad (CONABIO). México DF. $<$ https://www.biodiversidad.gob.mx/especies/gran_familia/ hongos/docs/Hongos.pdf $>$ (accessed, December 12, 2018).

Davoodian N, Bergemann SE, Hosaka K, Raspé O, Bougher N, Fechner NA, Henkel TW, Gelardi M, Soytong K, Naseer A, Ortiz-Santana B, Baroni TJ, Nagasawa E, Smith ME, Halling RE. 2018. A global view of Gyroporus: molecular phylogenetics, diversity patterns, and new species. Mycologia. DOI: https://doi.org/10.1080/00275514.2018.1511339

Fournier LA. 2003. Quercus oleoides Schltdl \& Cham. Species descriptions. Árboles en sistemas agroforestales. In: Cordero J, Boshier DH. eds. Árboles de Centroamérica. Costa Rica: OFI/CATIE, 683-684. ISBN: 0850741610

García E. 2004. Modificaciones al sistema de clasificación climática de Köppen. Ciudad de México: Instituto de Geografía. UNAM. ISBN 9703210104

García-Jiménez J, Garza-Ocañas F. 2001. Conocimiento de los hongos de la familia Boletaceae de México. Ciencia UANL 4: 336-343.

García-Jiménez J. 2013. Diversidad de Macromicetos en el estado de Tamaulipas, México. Ph.D. Dissertation, Universidad Autónoma de Nuevo León, México.

Halling RE, Mueller GM. 2005. Common Mushrooms of the Talamanca Mountains, Costa Rica. New York. New York Botanical Garden Press. ISBN: 978-0-89327-460-3

Halling RE, Chan HT, Lee SS. 2007. Basidiomycota: Boletaceae. In: Jones BG, Hyde KD, Vikineswary S. eds. Malaysian Fungal Diversity. Malaysia: Mushroom Research Centre, University of Malaya and Ministry of Natural Resources and Environment Malaysia, 33-45. ISBN: 9789832085935

Halling RE, Osmundson T, Neves MA. 2008. Pacific boletes: Implications for biogeographic relationships. Mycological Research 112: 437-447.

DOI: https://doi.org/10.1016/j.mycres.2007.11.021

Halling RE, Fechner N, Nuhn M, Osmundson T, Soytong K, Arora D, Binder M, Hibbett D. 2015. Evolutionary relationships of Heimioporus and Boletellus (Boletales), with an emphasis on Australian taxa including new species and new combinations in Aureoboletus, Hemileccinum and Xerocomus. Australian Systematic Botany. 28: 1-22.

DOI: https://doi.org/10.1071/SB14049

Heckman DS, Geiser DM, Eidell BR, Stauffer RL, Kardos NL, Hedges SB. 2001. Molecular evidence for the early colonization of land by fungi and plants. Science 293: 1129-1133. DOI: https://doi.org/10.1126/science.1061457 
Henkel TW, Aime M, Chin ML, Miller SL, Vilgalys R, Smith M. 2012. Ectomycorrhizal fungal sporocarp diversity and discovery of new taxa in Dicymbe monodominant forests of the Guiana Shield. Biodiversty and Conservation 21: 21952220. DOI: https://doi.org/10.1007/s10531-011-0166-1

Index Fungorum <http://www.indexfungorum.org/Names/ Names.asp $>$ (accessed September 5, 2018).

INEGI. 2009. Cuaderno estadístico municipal. Gobierno del estado de Tabasco y H. Ayuntamiento constitucional de Balancán, Tabasco, México. ISBN 9701323254

Küppers H. 2002. Atlas de los colores. Blume. Barcelona, España. ISBN: 9788480764209

Largent DL, Johnson D, Watling R. 1977. How to identify mushrooms to genus III: microscopic features. California: Eureka, Mad River Press. ISBN-10: 0916422097

Lodge DJ, Baroni TJ, Cantrell SA. 2002. Basidiomycetes of the Greater Antilles Project. In: Waltling R, Frankland J, Ainsworth AM, Robinson C. eds. Tropical Mycology volume I Macromycetes. Liverpool: CABI publishings, 45-60. ISBN 13: 9780851995427

López-Upton J, Ramírez-Herrera C, Jasso-Mata J, Jiménez-Casas M, Aguilera-Rodríguez M, Sánchez-Velázquez JR, Rodríguez-Trejo DA. 2011. Situación de los recursos genéticos forestales en México. Food and Agriculture Organization of the United Nations (FAO). ISBN 978-92-5-307275-0

Manos PS, Doyle JJ, Nixon KC. 1999. Phylogeny, biogeography, and processes of molecular differentiation in Quercus subgenus Quercus (Fagaceae). Molecular Phylogenetic Evolution 12: 333-349. DOI: https://doi.org/10.1006/mpev.1999.0614

Mata M. 1999. Macrohongos de Costa Rica Vol. 1. Santo Domingo de Heredia, Costa Rica: Instituto Nacional de Biodiversidad (INBio). ISBN-10: 9968702870

Matheny PB, Bougher NL. 2006. The new genus Auritella from Africa and Australia (Inocybaceae, Agaricales): molecular systematics, taxonomy and historical biogeography. Mycological Progress 5: 2-17.

DOI: https://doi.org/10.1007/s11557-005-0001-8

Mayor JR, Fulgenzi TD, Henkel TW, Halling RE. 2008. Boletellus piakaii sp. nov. and new distribution record for $B o-$ letellus ananas var. ananas from Guyana. Mycotaxon 105: 387-398.

Montoya L, Bandala V. 1991. Studies on the genus Phylloporus in México, I. Discussion of the known species and description of a new species and a new record. Mycotaxon 41: 471-482.

Neves MA, Halling RE. 2010. Study on species of Phylloporus I: Neotropics and North America. Mycologia 102: 923-943. DOI: https://doi.org/10.3852/09-215

Associated editor: Hilda Flores Olvera

Author contributions: EGC: collected field data, identified the specimens and wrote the text. SC: collected field data, corroborated the identifications, and revised the geographical distribution of the species based on published literature. JC: corroborated the identifications, revised the text and the dichotomous key. MTDLC: revised the text and the synonyms of the species.
Ortiz-Pérez MA, Siebe C, Cram S. 2005. Diferenciación Geográfica de Tabasco. In: Bueno J, Álvarez F, Santiago S. eds. Biodiversidad del Estado de Tabasco. Ciudad de México: Instituto de Biología, UNAM-CONABIO, 305-322. ISBN9799709000268

Ortiz-Santana B, Lodge JD, Baroni TJ, Both E. 2007. Boletes of Belize and the Dominican Republic. Funga Diversity 27: 247-416.

Osmundson TW, Halling RE. 2010. Tylopilus oradivensis sp. nov.: a newly described member of the Tylopilus balloui complex from Costa Rica. Mycotaxon 113: 475-483. DOI: https://doi.org/10.5248/113.475

Pennington D, Sarukhán J. 2005. Arboles Tropicales de México: Manual Para la Identificación de las Principales Especies. Ciudad de México: Universidad Nacional Autónoma de México. ISBN 10: 9681678559

Pérez-Mojica E, Valencia-A S. 2017. Estudio preliminar del género Quercus (Fagaceae) en Tamaulipas, México. Acta Botanica Mexicana 120: 59-111. DOI: https://doi.org/10.21829/ abm120.2017.1264

Pérez-Moreno J, Read DJ. 2004. Los hongos ectomicorrízicos, lazos vivientes que conectan y nutren a los árboles en la naturaleza. Interciencia 29: 239-247.

Prance GT. 1982. Biological diversification in the tropics. New York: Columbia University Press. ISBN-10: 0231048769

Romero-Rangel S, Rojas-Zenteno EC, Rubio-Licona E. 2015. Encinos de México. Universidad Nacional Autónoma de México.

Thiers HD. 1975. California Mushrooms: A Field Guide to the Boletes. Hafner Press: New York, NY. ISBN-13: 9780028534107; ISBN-10: 0028534107

Seehanan S, Petcharat V, Te-chato S. 2007. Some boletes of Thailand. Songklanakarin Journal of Science and Technology 29: 737-54.

Singer R. 1947. The Boletoideae of Florida. The Boletineae of Florida with notes on extralimital species III. The American Midland Naturalist 37: 1-135.

Singer R., Gómez LD. 1984. The Basidiomycetes of Costa Rica. III. The genus Phylloporus (Boletaceae). Brenesia 22:163181.

Singer R, García J, Gómez LD. 1992. The Boletineae of México and Central America IV. Beihefte zur Nova Hedwigia, Frankfurt. ISBN: 3443510272; 9783443510275

Smith AH, Thiers HD. 1971. The Boletes of Michigan. Michigan: The University of Michigan press. ISBN 10: 0472855905

Valencia-A S. 2004. Diversidad del género Quercus (FAGACEA) en México. Boletín de la Sociedad Botánica de México 75: 33-53. DOI: https://doi.org/10.17129/botsci.1692

Varela-Fregoso L, Mora-Velázquez A, Chávez-Hernández CG, Martínez-Bernal A, García-Sánchez R, Chimal-Sánchez E, Montaño MN. 2017. Acaulospora alpina and Ambispora fennica, two new records of arbuscular mycorrhizal fungi for México. Revista Mexicana de Biodiversidad 88: 496-501. DOI: https://doi.org/10.1016/j.rmb.2017.06.005

Zhishu B, Zheng G and Taihui L. 1993. The Macrofungus Flora of China's Guangdong Province. Hong Kong: Chinese University Press. ISBN: 9789622015562. 
González-Chicas et al. / Botanical Sciences 97 (3): 423-432. 2019

\section{Appendix 1: Coordinate and tropical boletoid species}

\begin{tabular}{|c|c|c|c|}
\hline \multicolumn{4}{|c|}{ Degrees and Decimal Minutes } \\
\hline LATITUDE & LONGITUDE & NAME & SPECIES \\
\hline $17^{\circ} 52.09083^{\prime}$ & $091^{\circ} 31.43317^{\prime}$ & Carretera Balancán -El Triunfo km 8.3 Sitio 1 & G. ballouii, B. auripes \\
\hline $17^{\circ} 52.16600^{\prime}$ & $091^{\circ} 31.48967^{\prime}$ & Carretera Balancán -El Triunfo km 8.3 Sitio 2 & $\begin{array}{l}\text { P. centroamericanus, } \\
\text { T. alboater }\end{array}$ \\
\hline $17^{\circ} 57.48500^{\prime}$ & $091^{\circ} 35.46383^{\prime}$ & $\begin{array}{l}\text { Rancho Don Filemón, camino Ej. El Pípíla-Ej. San Elpidio km } 0.5 \\
\text { Sitio } 1\end{array}$ & G. ballouii, B. auripes \\
\hline $17^{\circ} 57.58817^{\prime}$ & $091^{\circ} 34.96667^{\prime}$ & $\begin{array}{l}\text { Rancho Don Filemón, camino Ej. El Pípíla-Ej. San Elpidio km } 0.5 \\
\text { Sitio } 2\end{array}$ & $\begin{array}{l}\text { P. centroamericanus, } \\
\text { B. floridanus, B. vermiculosus }\end{array}$ \\
\hline $17^{\circ} 57.52550^{\prime}$ & $091^{\circ} 35.05733^{\prime}$ & $\begin{array}{l}\text { Rancho Don Filemón, camino Ej. El Pípíla-Ej. San Elpidio km } 0.5 \\
\text { Sitio } 3\end{array}$ & $\begin{array}{l}P . \text { indecisus, T. alboater, } \\
\text { B. ananas }\end{array}$ \\
\hline $17^{\circ} 57.29567^{\prime}$ & $091^{\circ} 35.60017^{\prime}$ & $\begin{array}{l}\text { Rancho Don Filemón, camino Ej. El Pípíla-Ej. San Elpidio km } 0.5 \\
\text { Sitio } 4\end{array}$ & $\begin{array}{l}\text { G. castaneus, } P \text {. indecisus, } \\
\text { B. vermiculosus, } B \text {. floridanus }\end{array}$ \\
\hline
\end{tabular}

